\title{
Effect of Site Specific Drip Fertigation on Yield of Chilli
}

\author{
Dr. Abdul Hakkim, V.M., \\ Principal Investigator, Precision Farming Development Centre, Kerala Agricultural University, KCAET, \\ Tavanur (P.O.), Malappuram (Dist), Kerala - 679 573, India.
}

\begin{abstract}
Two test plots, one from high fertility zone and one from low fertility zone were identified and delineated with the help of GPS for raising the test crop. Soil samples were collected from the experimental sites one month before planting. The samples were analyzed for available N, P and K. Site specific nutrient recommendations were made using the Decision Support System for Integrated Fertilizer Recommendation (DSSIFER) software (Murugappan et al. 2004) for optimum yield. Field experiments were conducted to evaluate the effect of site specific drip fertigation in completely randomized design (CRD) with six treatments and four replications. Hybrid chilli (hot line) was used as the test crop. Package of practices were carried out as per the recommendations. Relevant observations on growth parameters at periodic intervals and yield parameters of chilli were recorded and economics viz., gross return, net return and Benefit Cost Ratio (BCR) were calculated. Drip irrigation was scheduled daily ( $24 \mathrm{hrs})$ and once in two days ( $48 \mathrm{hrs}$ ) based on the treatments with the computed quantity of water. Phosphorous was applied as one basal dose and two top dressings in the form of super phosphate in three split doses (basal, 30 DAP and 60 DAP). Nitrogen and potassium were applied through fertigation system. Fertigation was done once in five days starting from 15 DAP up to $150 \mathrm{DAP}$.
\end{abstract}

The highest total green fruit yield was recorded under the treatment site specific drip fertigation with daily drip irrigation for low fertility area, whereas there was no significant difference between the total yield under the treatments site specific drip fertigation and recommended dose drip fertigation along with daily drip irrigation for high fertility area. The different yield parameters like fruit length, fruit girth, fruit weight and number of fruits per plant also varied in the same trend as that of total green fruit yield. In case of low fertility area, highest BCR was obtained for the treatment site specific drip fertigation and daily drip irrigation (2.42) followed by the treatment site specific drip fertigation and alternate day drip irrigation (2.25). The lowest BCR was obtained under the treatment with manual application of fertilizer and alternate day drip irrigation (1.91). In case of high fertility area, corresponding values of BCR were 2.47.2.43 and 2. 17 respectively.

\section{INTRODUCTION}

Precision agriculture is that which uses inputs most efficiently and judiciously to maximize productivity and profitability with minimum impact on soil and environment. Precision in terms of both time and quantity of inputs and agronomic practices, envisages a prospect, which can help in decreasing the cost of production and not having any adverse effect on soil and environmental health. Thus the intent of precision farming is to match agricultural inputs and practices to localized conditions within a field to do the right thing in the right place, at the right time and in the right way. Precision farming basically depends on measurement and understanding of variability. Efficient use of available irrigation water is essential for increasing agricultural productivity for the alarming Indian population. With present potential of 114 million hectare meters (mha.m) of water, only 97 mha is under irrigation in India, for the total cultivated area of 145 mha.

Efficient management of water resources is essential to meet the increasing competition for water between agricultural and non-agricultural sectors and the present day share of 80 per cent of water used for agriculture is anticipated to be reduced by 70 per cent in the coming decade. This necessitates scientific management of available water resources, particularly in agricultural sector. Sustainability of any system requires optimal utilization of resources such as water, fertilizer and soil. Apart from the economic considerations, the adverse effect of injudicious use of water and fertilizers on the environment can have far reached implications. There is a need to develop agro technologies, which will help in sustaining the precious resources and maximize the crop production, without any detrimental impact on the environment.

Bringing more area under irrigation would depend largely upon efficient use of water. In this context, micro irrigation has most significant role to achieve not only higher productivity and water use efficiency but also to have sustainability with economic use and productivity. Fertilizer management is the most important agro-technique, which controls development, yield and quality of a crop. Fertilizer use efficiency is only 50 per cent in conventional practice 
of soil application. Location specific fertilizer management practices are essential for increasing fertilizer use efficiency for optimizing the fertilizer input and maximizing the productivity. Every attempt is therefore necessary, in achieving this objective of higher water and fertilizer use efficiency. Under these circumstances, drip fertigation, which is known to be hi-tech and efficient way of applying fertilizers through irrigation system as a carrier and distributor of crop nutrients, holds bright promise (Magen, 1995).

Maximization of crop yield, quality and minimization of leaching loss of nutrients below the rooting zone could be achieved by managing fertilizer concentrations in measured quantities of irrigation water using drip irrigation (Hagin and Lowengart, 1995). Fertigation has been found to be effective in saving labour and energy. Fertigation increases both water and nutrient use efficiency. It supplies nutrients directly to the root zone in available forms and hence it regulates the nutrient balance and prevents loss of nutrients. It offers flexibility in fertilizer application to match crop's nutritional requirement at different growth stages. Prabhakar and Hebbar (1999) based on field trials conducted at IIHR, Bangalore reported that highest fruit yield of capsicum hybrid green gold was obtained with 100 per cent fertigation using water soluble fertilizers, irrigated at 0.7 Epan level. The higher yield was the result of better plant growth coupled with yield components like more number of marketable fruits per plant and higher fruit size. This yield was nearly two and a half times that capsicum grown at 0.5 Epan without fertigation. Benefits of fertigation over traditional broadcast or drop fertilizing methods include:

- Increased nutrient absorption by plants,

- Reduction in fertilizer and chemicals needed,

- Reduction in water usage due to increased root mass being able to trap and hold water,

- Reduced leaching to the water table, and

- Nutrients are applied near the root zone of the crop, hence the crop responds very well.

Introduction of simultaneous micro irrigation and fertigation opened up new possibilities for controlling water and nutrient supplies to crops and maintaining the desired concentration and distribution in the soil. By introducing fertigation, it is possible to increase the yield potential by three times with the same quantity of water, by saving about 45 to 50 per cent of irrigation water and increasing the productivity by about 40 per cent. When fertilizer is applied through drip irrigation, it was observed that the yield has been increased and about 30 per cent of the fertilizer could be saved (Sivanappan and Ranghaswami, 2005). Fertigation is supplying fertilizers along with irrigation is one of the most effective of convenient method of supplying nutrients of water according to the specific requirements of the crop to maintain optimum soil fertility and to increase the quality of the produce (Shingure et al., 2000). Optimum plant growth is a function of nutrient concentration in the plant. There is a critical nutrient concentration, below which growth is reduced/terminated. The adequate zone is above the critical concentration and provides maximum growth. The toxic zone is above the adequate zone, again resulting in reduced growth or death. Therefore, more is not always better!

Chilli (Capsicum annuиm L.) is a condiment cum vegetable crop valued for its taste and pungency. Chilli or hot pepper is the second largest commodity after black pepper (Piper nigrum L.) in the international trade. Chillies are indispensable ingredient used in every Indian diet due to its pungency, spicy taste and appealing colour and flavour. It has two important qualities, the pungency due to a crystalline acrid volatile alkaloid called 'Capsaicin' and captivating red colour due to the pigment 'Capsanthin'. Chilli plays a dominant role in the preparation of pickles, sauce and ketchup. Powder of chilli is used for cooking. Capsaicin has diverse prophylactic and therapeutic uses in ayurvedic and allopathic medicines. Hence, chilli finds a diverse use as spice, condiment, culinary supplement, medicine and vegetable. The present studies were carried out on chilli crop for vegetable purpose. Chilli being a long duration crop, maintaining optimum soil moisture and nutrient status throughout the growth period is crucial for getting higher yields.

Keeping the above points in view, field studies were carried out with the following objectives.

1. To study the response of site specific nutrient application with reference to the derived fertility zones by conducting field experiments using the hybrid chilli (Capsicum annum.L.) variety "hotline".

2. To study the soil moisture dynamics under different fertigation treatments.

3. To evaluate the economic feasibility of site specific drip fertigation system.

\section{MATERIALS AND METHODS}

The study was conducted in the farmers' field located at Thondamuthur, Coimbatore district, during the period of $2007-2009$. The study area of 50 ha is located between $10^{\circ} 59^{\prime} 26^{\prime \prime}$ and $10^{\circ} 59^{\prime} 31^{\prime \prime} \mathrm{N}$ latitude, $76^{\circ} 50^{\prime}$ 4 " and $76^{\circ} 50^{\prime} 15^{\prime \prime} \mathrm{E}$ longitude with an average altitude of $500 \mathrm{~m}$ above MSL. Field studies were conducted during the kharif season of 2007 and 2008. Two test plots, one from low fertility area and other from high fertility area were selected for the study. In both the test plots, the soil belongs to Thondamuthur series, having 
sandy loam soil (texture). The detailed physio-chemical properties of the soils are given in Table 1. Chilli (Capsicum annuum L.) hybrid 'Hotline' variety was used for the study. The experimental plot was laid out in a completely randomized design with six treatments and four replications. Soil samples were collected from the experimental sites one month before planting. The samples were analyzed for available N, P and K. Site specific nutrient recommendations were made using the Decision Support System for Integrated Fertilizer Recommendation (DSSIFER) software (Murugappan et al. 2004) for optimum yield. The field layout plan for the experimental plots is depicted in Fig. 1. The treatment details are as follows:

T1 - Recommended dose of fertilizer for the crops (as per the package of practice recommendations) through drip fertigation, providing daily drip irrigation.

T2 - Recommended dose of fertilizer for the crops (as per the package of practice recommendations) through drip fertigation, providing alternate day drip irrigation.

T3 - Fertilizer dose based on the available nutrients in the field obtained from the nutrient status map through drip fertigation, providing daily drip irrigation.

T4- Fertilizer dose based on the available nutrients in the field obtained from the nutrient status map through drip fertigation, providing alternate day drip irrigation.

T5 - Manual application of fertilizer along with daily drip irrigation.

T6 - Manual application of fertilizer along with alternate day drip irrigation.

Table 1. Soil characteristics of the test fields

\begin{tabular}{|l|l|r|r|}
\hline \multicolumn{1}{|c|}{ Soil characteristics } & \multicolumn{1}{|c|}{ Particulars } & Plot No. 1 & \multicolumn{1}{c|}{ Plot No. 2 } \\
\hline Textural composition & Sand, per cent (\%) & 62 & 58 \\
& Silt, per cent (\%) & 33 & 35 \\
& Clay, per cent (\%) & 5 & 7 \\
& Textural class & Sandy loam & Sandy loam \\
\hline Chemical properties & Available N, Kg/ha & 216.36 & 106.32 \\
& Available P, Kg/ha & 21.32 & 11.13 \\
& Available K, Kg/ha & 629.83 & 274.21 \\
& pH & 7.92 & 7.72 \\
& Electrical conductivity (dSm $\left.{ }^{-1}\right)$ & 0.27 & 0.19 \\
\hline Physical characters & Bulk density, g/cc & 1.61 & 1.67 \\
& Field capacity, per cent & 22.73 & 23.07 \\
& Permanent wilting point, per cent & 11.68 & 11.84 \\
& Infiltration rate, cm/hr & 1.92 & 1.81 \\
\hline
\end{tabular}

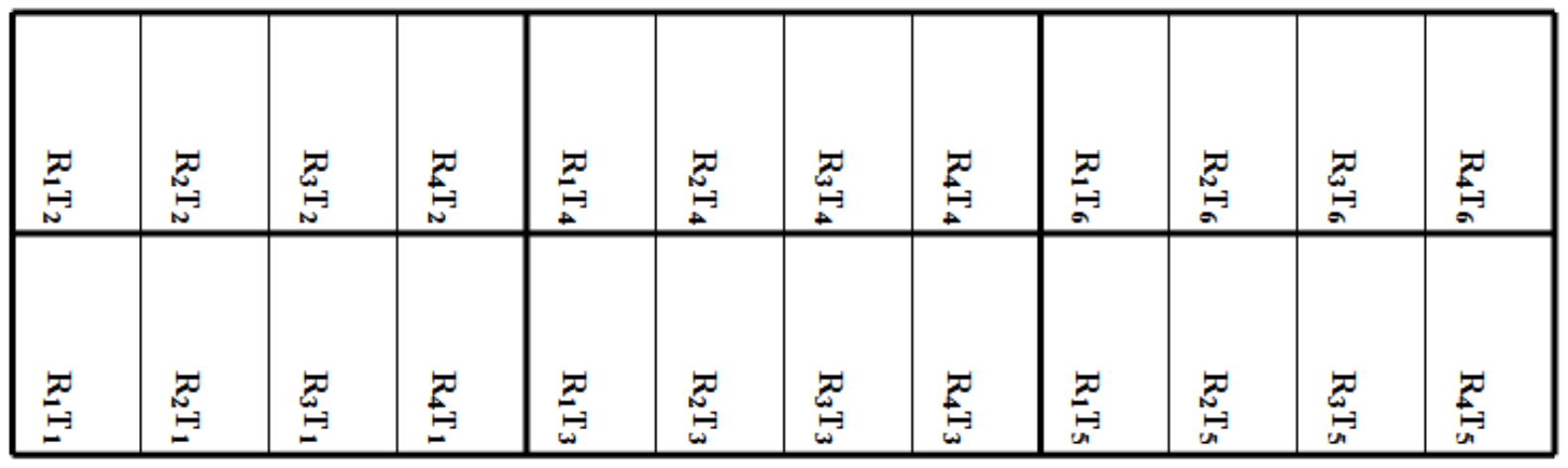

Fig. 1 Field layout plan of experimental plots

\subsection{Design and Layout of the Drip System \\ 1 .}

The design of the drip system is essentially a decision regarding selection of emitters, laterals and manifolds, sub main, main line and required pumping unit. The size of main, sub-mains, laterals and pumps were decided based on the desired flow rate and pressure head in the system. Pressure drop due to friction in laterals and sub main was estimated using Hazen - William empirical equation for multiple outlet pipes. In the present study, the existing pumping system used by the farmers for irrigation was considered for the system and the flow and pressure requirement was regulated with the help of control valves. To economize the drip installation cost for 
chilli based on the wetting zone in the soil for 4 lph emitter, the spacing of lateral and spacing between emitters were selected as $1.5 \mathrm{~m}$ and $0.6 \mathrm{~m}$ respectively (Selvaraj, 1997). Water was pumped from the source through a $15 \mathrm{HP}$ submersible pump and conveyed to the field using $63 \mathrm{~mm}$ diameter PVC pipes. From the main line, sub main lines of $63 \mathrm{~mm}$ and $50 \mathrm{~mm}$ diameter PVC pipes were taken off. From the sub main lines, inline emitter lateral lines of $16 \mathrm{~mm}$ LLDPE pipes were taken on both the sides to irrigate the plots. The application of fertilizer to various treatments was controlled by using control valves provided in the sub main and lateral flow control valves provided at the off take of laterals. Laterals were provided with end caps. The arrangement was done in such way that different treatment areas can be fertigated separately as per requirement and irrigation water can be applied daily or alternate day on either side of the sub main depending upon the irrigation interval fixed for various treatments. After installation, trial run was conducted to assess mean emitter discharge and uniformity coefficient. This was taken into account for fixing the irrigation water application time. During the irrigation period an average co-efficient of 90 to 95 per cent was maintained. The design Data of the drip irrigation system and the experimental details for the test plots are given in Table 2.

The fertilizer sources for supplying $\mathrm{N}$ and $\mathrm{K}$ through drip irrigation were urea and muriate of potash respectively. Phosphorous was applied as top dressing in the form of super phosphate. The fertigation schedule followed for different treatments in both experimental plots are furnished in Table 3.6. Fertigation was done once in five days starting from 15 DAP up to 155 DAP, regulated by control valves and taps provided near the take off points of the sub main. As and when the chilli fruits attained the stage suitable for vegetable purpose (green chilli), they were harvested. The matured fruits at harvested stage were picked and the yield obtained in each picking was weighed, accounted and summed up to obtain the total green chilli yield per plot from which the yield per hectare was worked out.

Table 2. Experimental details

\begin{tabular}{|l|l|l|}
\hline Parameter & Plot No.1 & Plot No.2 \\
\hline Size of the test plot & $81 \mathrm{~m}$ x $26 \mathrm{~m}$ & $63 \mathrm{~m}$ x $26 \mathrm{~m}$ \\
\hline Total area of the test plot & $52.65 \mathrm{cents}$ & $40.95 \mathrm{cents}$ \\
\hline Length of 63 mm diameter sub main & $60 \mathrm{~m}$ & $50 \mathrm{~m}$ \\
\hline Length of 50 mm sub main & $27 \mathrm{~m}$ & $21 \mathrm{~m}$ \\
\hline Length of each lateral from sub main (16mm OD LLDPE) & $13 \mathrm{~m}$ & $13 \mathrm{~m}$ \\
\hline Total number of laterals from sub main & 108 Nos. & 84 Nos. \\
\hline Number of emitters per lateral & 21 Nos. & $21 \mathrm{Nos}$. \\
\hline Lateral spacing & $1.5 \mathrm{~m}$ & $1.5 \mathrm{~m}$ \\
\hline Emitter type & Inline & Inline \\
\hline Emitter discharge rate & 4 lph & 4 lph \\
\hline Filter size (Screen filter) & $63 \mathrm{~mm}$ & $63 \mathrm{~mm}$ \\
\hline Fertilizer tank capacity & 30 litres & 30 litres \\
\hline Treatment plot size & $27 \times 13 \mathrm{~m}$ & $21 \mathrm{x} 13 \mathrm{~m}$ \\
\hline No. of treatments & 6 & 6 \\
\hline No. of laterals / treatment & 18 Nos. & 14 Nos. \\
\hline No. of plant rows / treatment & 36 Nos. & 28 Nos. \\
\hline No. of plants / row & 21 Nos. & $21 \mathrm{Nos}$. \\
\hline Planting pattern & Paired row & Paired row \\
\hline Total no. of plants/treatment & 756 Nos. & 588 Nos. \\
\hline Spacing of plants & 60 x 60 m & 60 x 60 m \\
\hline No. of laterals / replication & 4 Nos. & 3 Nos. \\
\hline
\end{tabular}

\subsection{Yield and Yield Components}

(Source: FAO Irrigation and Drainage paper No. 56)

Length of the fruit was measured in the tagged plants at random from the calyx end to the tip of the fruit in all treatments and the mean was expressed in $\mathrm{cm}$. The girth of fruit was measured at the broadest point and expressed in centimeter. Five randomly selected matured fruits from each treatment were weighed and the mean was calculated and expressed in gram. The number of fruits harvested from five randomly selected plants over eight harvests was counted and the mean was expressed in number. The fruits harvested from five randomly selected plants over all harvests were weighed; the mean was worked out and expressed in grams. The green chilli yield per plot was weighed and summed to arrive total green chilli yield per net plot which was converted and expressed in tonnes/ ha.

\subsection{Economics}


The expenditure incurred from field preparation to harvest was worked out and expressed as Rs/. ha. The green chilli yield was computed per hectare and the total income was worked out based on the prevailed minimum market rate of Rs. 10.00 per Kg. Net returns were obtained by subtracting the cost of cultivation from gross return. The cost of drip system for one hectare was worked out based on current market rates. The life of the drip system was assumed to be 6 years. Prevailing market price of drip components from a standard firm was used. Interest on capital investment was taken as 8.0 per cent per annum.

The benefit cost ratio (BCR) was worked out by using the formula suggested by Palaniappan (1985).

$$
\mathrm{BCR}=\frac{\text { Gross return }\left(\mathrm{Rs} . \mathrm{ha}^{-1}\right)}{\text { Total cost of cultivatio } \mathrm{n}\left(\mathrm{Rs} . \mathrm{ha}^{-1}\right)}
$$

\subsection{Statistical Analysis}

The Data on various parameters studied during the course of investigation were statistically analysed, applying the technique of analysis of variance suggested by Panse and Sukhatme (1978). Wherever the treatment differences were found significant, ('F' test) critical difference was worked out at five per cent probability level. The treatment differences that were not significant were denoted by "NS".

\subsection{Yield and Yield Parameters}

\section{RESULTS AND DISCUSSION}

The fruit characteristics recorded after every picking and the average values are expressed under various treatments are shown in Tables 3 and 4.

Table 3. Effect of fertigation Yield parameters of chilli for low fertility area

\begin{tabular}{|c|r|r|r|r|r|r|}
\hline \multirow{2}{*}{ Treatment } & \multicolumn{7}{|c|}{ Parameter } \\
\cline { 2 - 7 } & $\begin{array}{c}\text { No. of } \\
\text { fruits/plant }\end{array}$ & $\begin{array}{c}\text { Fruit } \\
\text { length } \\
\text { (cm) }\end{array}$ & $\begin{array}{c}\text { Fruit } \\
\text { girth } \\
\text { (cm) }\end{array}$ & $\begin{array}{c}\text { Fruit } \\
\text { weight } \\
\text { (gm) }\end{array}$ & $\begin{array}{c}\text { Fruit } \\
\text { yield } \\
\text { (g/plant) }\end{array}$ & $\begin{array}{r}\text { Fruit } \\
\text { yield } \\
\text { (t/ha) }\end{array}$ \\
\hline TI & 112.10 & 15.52 & 4.90 & 9.468 & 1061.33 & 22.86 \\
\hline T2 & 108.35 & 15.35 & 4.92 & 9.385 & 1016.86 & 21.90 \\
\hline T3 & 119.33 & 16.52 & 5.27 & 10.003 & 1193.62 & 25.71 \\
\hline T4 & 114.15 & 15.93 & 4.96 & 9.660 & 1102.66 & 23.75 \\
\hline T5 & 106.58 & 14.68 & 4.35 & 9.088 & 968.53 & 20.86 \\
\hline T6 & 105.34 & 14.21 & 4.19 & 8.938 & 941.44 & 20.28 \\
\hline Mean & 110.97 & 15.37 & 4.76 & 9.423 & 1047.41 & 22.56 \\
\hline S.E.D & 0.52 & 0.23 & 0.06 & 0.07 & 10.15 & 0.22 \\
\hline CD(0.01) & $1.50 * *$ & $0.66 * *$ & $0.17 * *$ & $0.21 * *$ & $29.21 * *$ & $0.63 * *$ \\
\hline CD (0.05) & 1.09 & 0.48 & 0.12 & 0.16 & 21.32 & 0.46 \\
\hline
\end{tabular}

* - significant at $5 \%$ level, **- significant at $1 \%$ level, NS - not significant.

Table 4. Effect of fertigation Yield parameters of chilli for high fertility area

\begin{tabular}{|c|r|r|r|r|r|r|}
\hline \multirow{2}{*}{ Treatment } & \multicolumn{7}{|c|}{ Parameter } \\
\cline { 2 - 7 } & $\begin{array}{c}\text { No. of } \\
\text { fruits/plant }\end{array}$ & $\begin{array}{c}\text { Fruit } \\
\text { length } \\
\text { (cm) }\end{array}$ & $\begin{array}{c}\text { Fruit } \\
\text { girth } \\
\text { (cm) }\end{array}$ & $\begin{array}{c}\text { Fruit } \\
\text { weight } \\
\text { (gm) }\end{array}$ & $\begin{array}{c}\text { Fruit } \\
\text { yield } \\
\text { (g/plant) }\end{array}$ & $\begin{array}{r}\text { Fruit } \\
\text { yield } \\
\text { (t/ha) }\end{array}$ \\
\hline TI & 119.23 & 16.59 & 5.33 & 9.998 & 1191.94 & 25.67 \\
\hline T2 & 116.65 & 16.40 & 5.20 & 9.948 & 1160.37 & 24.99 \\
\hline T3 & 119.20 & 16.54 & 5.32 & 9.995 & 1191.38 & 25.66 \\
\hline T4 & 116.62 & 16.33 & 5.19 & 9.945 & 1159.79 & 24.98 \\
\hline T5 & 113.73 & 15.69 & 4.98 & 9.705 & 1103.72 & 23.77 \\
\hline T6 & 111.10 & 15.34 & 4.89 & 9.640 & 1071.01 & 23.07 \\
\hline Mean & 116.09 & 16.15 & 5.15 & 9.87 & 1146.37 & 24.69 \\
\hline S.E.D & 0.35 & 0.07 & 0.05 & 0.04 & 5.05 & 0.11 \\
\hline CD(0.01) & $1.02 * *$ & $0.19 * *$ & $0.13 * *$ & $0.11 * *$ & $14.53 * *$ & $0.32 * *$ \\
\hline CD (0.05) & 0.74 & 0.14 & 0.09 & 0.08 & 10.61 & 0.23 \\
\hline
\end{tabular}

* - significant at $5 \%$ level, **- significant at $1 \%$ level, NS - not significant.

In case of low fertility area the fruit length increased with increased rate of fertigation, whereas no significant 
increase in fruit length was observed with increased rate of fertilizer application in high fertility area. Highest fruit length of $16.52 \mathrm{~cm}$ was recorded for site specific drip fertigation with daily drip irrigation in case of low fertility area followed by $15.93 \mathrm{~cm}$ for site specific drip fertigation with alternate day drip irrigation. The lowest fruit length was observed for the treatment with manual fertilizer application and alternate day drip irrigation. In case of high fertility area there was no significant difference in fruit length among all treatments with fertigation and the fruit length values were lower for the treatments with manual fertilizer application. Similar to fruit length, fruit girth also varied with variation in fertilizer levels in case of low fertility area. In case of low fertility area, the highest fruit girth was recorded under the treatment site specific drip fertigation providing daily drip irrigation and was $5.27 \mathrm{~cm}$ and the lowest value was $4.19 \mathrm{~cm}$ for the treatment with manual fertilizer application and alternate day drip irrigation. In case of high fertility area there was no significant difference in fruit girth along with variation in dose of applied fertilizer. Highest fruit girth was noted for the treatment with site specific drip fertigation providing daily drip irrigation through drip. Stem girth were found low in case of treatments with manual fertilizer application for both the plots. Fruit weight is directly proportional to the fruit length and fruit girth in case of all the treatments under both the experiments. In case of low fertility area, the fruit weight varied directly with the rate of fertilizer applied, whereas there was no significant effect of applied fertilizer on fruit weight in case of high fertility area. The method of fertilizer application had significant effect on fruit weight in high fertility area. The highest average single fruit weight was 9.998 and $9.995 \mathrm{~g}$ for recommended dose drip fertigation and site specific drip fertigation for high fertility area, whereas it was 9.468 and $10.003 \mathrm{~g}$ respectively in case of low fertility area. It was noticed that all fruit characteristics varied in the same manner for all the treatments in both the fields.

Generally, the number of fruits per plant was higher in high fertility area compared to the low fertility area. The highest number of fruits obtained for low fertility area was (119.33) under site specific drip fertigation providing daily drip irrigation, which was closer to that for site specific drip fertigation and recommended dose drip fertigation with daily drip irrigation (119.20 and 119.23 respectively) under high fertility area. Number of fruits per plant was increased with increase in drip irrigation levels and fertilizer levels, during both the experiments. In both fields alternate day drip irrigation treatments yielded lesser number of fruits compared to daily drip irrigation treatments. The lowest number of fruits was recorded in the treatment which received alternate day drip irrigation along with manual fertilizer application in both experiments.

The green chilli fruit yield per plant recorded at different picking was summed up to get the total green fruit yield per plant. Generally, the green fruit yield /plant was higher for high fertility area than low fertility area. The total green fruit yield /plant recorded with site specific drip fertigation along with daily drip irrigation for low fertility area was $1183.619 \mathrm{~g} /$ plant, which was comparable with that for site specific drip fertigation and recommended dose drip fertigation providing daily drip irrigation for high fertility area (1191.380 and 1191.936 $\mathrm{g} /$ plant respectively). In case of low fertility area, the lowest yield per plant was $20.46 \%$ less than that of the highest plant yield, whereas it was $10.15 \%$ of the highest plant yield in case of high fertility area. Therefore it would be better to go with site specific drip fertigation along with daily drip irrigation for achieving the maximum total green fruit yield /plant.

Irrigation interval and fertilizer levels significantly influenced green chilli fruit yield for both the test fields. The green chilli yield per ha was worked out by multiplying the green chilli yield per plant with total number of plants per hectare. As the crop spacing was the same for both experiments, the total number of plants per hectare also remained the same (Table 4.15 and 4.16). Hence the variation of green chilli fruit yield per hectare was in the same manner as the variation of green chilli fruit yield per plant. The yield from net plot area under various treatments were recorded for each picking and summed up at the final picking and was presented as total green fruit yield in t/ha. Generally, the green fruit yield/ ha was higher for high fertility area when compared to low fertility area.

There was a significant difference in total green fruit yield owing to different moisture regimes by different intervals of drip irrigation in both fertility areas. The highest total green fruit yield ( $25.49 \mathrm{t} / \mathrm{ha})$ was recorded under the treatment site specific drip fertigation with daily drip irrigation for low fertility area, whereas there was no significant difference between the total yield under the treatments site specific drip fertigation and recommended dose drip fertigation both with daily drip irrigation for high fertility area (25.66 and $25.67 \mathrm{t} / \mathrm{ha}$ respectively). In both the fields lowest yield was recorded under the treatment manual fertilizer application along with alternate day drip irrigation and the values were 20.27 and $23.07 \mathrm{t} / \mathrm{ha}$ for low fertility and high fertility area respectively. Interaction effect of irrigation interval and fertilizer levels was significant in green fruit yield at each picking for low fertility area; whereas it was not significant with fertilizer levels in case of high fertility area though the way of application of fertilizer had influence on yield in both test fields. 


\subsection{Economics}

The Data on the economics of drip irrigation for chilli in one hectare are presented in Tables 5 and 6.

Table 5. Cost Economics of site specific drip fertigation for chilli in 1 ha for low fertility area

\begin{tabular}{|c|c|c|c|c|c|c|c|}
\hline \multirow{2}{*}{$\begin{array}{l}\text { Sl. } \\
\text { No. }\end{array}$} & \multirow[t]{2}{*}{ Description } & \multicolumn{6}{|c|}{ Treatments } \\
\hline & & T1 & $\mathbf{T 2}$ & T3 & T4 & T5 & T6 \\
\hline 1 & Fixed cost $(\mathrm{Rs})$ & 90788 & 90788 & 90788 & 90788 & 90788 & 90788 \\
\hline & Life (Years) & 6 & 6 & 6 & 6 & 6 & 6 \\
\hline & Annual cost (Rs) & 15131 & 15131 & 15131 & 15131 & 15131 & 15131 \\
\hline & Interest@8\% (Rs) & 7263 & 7263 & 7263 & 7263 & 7263 & 7263 \\
\hline & Repair and maintenance (Rs) & 1385 & 1385 & 1385 & 1385 & 1385 & 1385 \\
\hline & Total Cost (Rs) (A) & 23779 & 23779 & 23779 & 23779 & 23779 & 23779 \\
\hline 2 & $\begin{array}{l}\text { Cost of cultivation, (Rs/ha) } \\
\text { (B) }\end{array}$ & 61005 & 60505 & 61243 & 60743 & 61805 & 61305 \\
\hline 3 & $\begin{array}{l}\text { Seasonal total cost }(\mathrm{Rs}) \\
(\mathbf{C}=\mathbf{A}+\mathbf{B})\end{array}$ & 84784 & 84284 & 85022 & 84522 & 85584 & 85084 \\
\hline 4 & Yield produced (t/ha) & 22.859 & 21.902 & 25.709 & 23.750 & 20.861 & 20.277 \\
\hline 5 & Selling price $(\mathrm{Rs} / \mathrm{t})$ & 8000 & 8000 & 8000 & 8000 & 8000 & 8000 \\
\hline 6 & $\begin{array}{l}\text { Income from produce }(\mathrm{Rs}) \\
\text { (D) }\end{array}$ & 182872 & 175216 & 205672 & 190000 & 166888 & 162216 \\
\hline 7 & $\begin{array}{l}\text { Net seasonal income }(\mathrm{Rs}) \\
\mathbf{E}=(\mathbf{D}-\mathbf{C})\end{array}$ & 98088 & 90932 & 120650 & 105478 & 81304 & 77132 \\
\hline 8 & $\begin{array}{l}\text { Benefit }- \text { Cost ratio } \\
\mathbf{F}=(\mathbf{D} / \mathbf{C})\end{array}$ & 2.16 & 2.08 & 2.42 & 2.25 & 1.95 & 1.91 \\
\hline
\end{tabular}

Table 6. Cost Economics of site specific drip fertigation for chilli in $\mathbf{1}$ ha for high fertility area

\begin{tabular}{|c|c|c|c|c|c|c|c|}
\hline \multirow{2}{*}{$\begin{array}{l}\text { Sl. } \\
\text { No. }\end{array}$} & \multirow[t]{2}{*}{ Description } & \multicolumn{6}{|c|}{ Treatments } \\
\hline & & T1 & $\mathbf{T 2}$ & T3 & T4 & T5 & T6 \\
\hline \multirow[t]{6}{*}{1} & Fixed cost $(\mathrm{Rs})$ & 90788 & 90788 & 90788 & 90788 & 90788 & 90788 \\
\hline & Life (Years) & 6 & 6 & 6 & 6 & 6 & 6 \\
\hline & Annual cost (Rs) & 15131 & 15131 & 15131 & 15131 & 15131 & 15131 \\
\hline & Interest @ 8\% (Rs) & 7263 & 7263 & 7263 & 7263 & 7263 & 7263 \\
\hline & Repair and maintenance(Rs) & 1385 & 1385 & 1385 & 1385 & 1385 & 1385 \\
\hline & Total Cost (Rs) (A) & 23779 & 23779 & 23779 & 23779 & 23779 & 23779 \\
\hline 2 & $\begin{array}{l}\text { Cost of cultivation, (Rs/ha) } \\
\text { (B) }\end{array}$ & 61005 & 60505 & 59212 & 58712 & 61805 & 61305 \\
\hline 3 & $\begin{array}{l}\text { Seasonal total cost }(\mathrm{Rs}) \\
(\mathbf{C}=\mathbf{A}+\mathbf{B})\end{array}$ & 84784 & 84284 & 82991 & 82491 & 85584 & 85084 \\
\hline 4 & Yield produced (t/ha) & 25.672 & 24.993 & 25.660 & 24.980 & 23.772 & 23.068 \\
\hline 5 & Selling price $(\mathrm{Rs} / \mathrm{t})$ & 8000 & 8000 & 8000 & 8000 & 8000 & 8000 \\
\hline 6 & $\begin{array}{l}\text { Income from produce (Rs) } \\
\text { (D) }\end{array}$ & 205376 & 199944 & 205280 & 199840 & 190176 & $\begin{array}{r}18454 \\
4\end{array}$ \\
\hline 7 & $\begin{array}{l}\text { Net seasonal income }(\mathrm{Rs}) \\
\mathbf{E}=(\mathbf{D}-\mathbf{C})\end{array}$ & 120592 & 115660 & 122289 & 117349 & 104592 & 99460 \\
\hline 8 & $\begin{array}{l}\text { Benefit }- \text { Cost ratio } \\
\mathbf{F}=(\mathbf{D} / \mathbf{C})\end{array}$ & 2.42 & 2.37 & 2.47 & 2.43 & 2.22 & 2.17 \\
\hline
\end{tabular}

The life span of drip system varies from 6 to 10 years depending upon quality and maintenance of drip system. Hence a normal life span of 6 years was considered for computation. Though the initial capital investment was high due to drip irrigation system, the cumulative benefit would be greater, considering the longer life of the 
system. The fixed cost towards installation of drip system was worked out to be Rs. 90788/ ha taking into the prevailing rate. For low fertility area, highest seasonal net income was recorded for the treatment with site specific drip fertigation and daily drip irrigation (Rs. 120650.00), followed by the treatment with site specific drip fertigation and alternate day drip irrigation (Rs. 105478.00). The lowest net seasonal income was recorded for the treatment with manual application of fertilizer and alternate day drip irrigation (Rs. 77132.00) followed by the treatment with manual application of fertilizer and daily drip irrigation(Rs. 81304.00), though the highest seasonal cost (Rs. 85584.00) was also recorded for this treatment. The Benefit - Cost Ratio (BCR) values worked for various treatments show that highest BCR was recorded with the treatment site specific drip fertigation and daily drip irrigation (2.42) followed by the treatment with site specific drip fertigation and alternate day drip irrigation (2.25). The lowest BCR was recorded under the treatment with manual application of fertilizer and alternate day drip irrigation (1.91).

For high fertility area, highest seasonal net income was recorded for the treatment with site specific drip fertigation and daily drip irrigation (Rs. 122289.00). The lowest net seasonal income was recorded for the treatment with manual application of fertilizer and alternate day drip irrigation (Rs. 99460.00) followed by the treatment with manual application of fertilizer and daily drip irrigation (Rs. 104592.00), though the highest seasonal cost (Rs. 85584.00) was also recorded for this treatment. The BCR values worked for various treatments show that highest BCR was recorded with the treatment site specific drip fertigation and daily drip irrigation (2.47) followed by the treatment with site specific drip fertigation and alternate day drip irrigation (2.43). The lowest BCR was recorded under the treatment with manual application of fertilizer and alternate day drip irrigation (2.17).

In low fertility area, though there was an additional cost of Rs.238.00/ha for fertilizer in the treatment with site specific drip fertigation and daily drip irrigation when compared with recommended dose drip fertigation and daily drip irrigation, there was an additional return of Rs. 22800.00/ha by way of increased yield due to site specific drip fertigation. This is the reason for recording high BCR for the treatment with site specific drip fertigation daily drip irrigation, compared to other treatments in low fertility area. In high fertility area, the impact of site specific drip fertigation was by way of savings in fertilizer cost. In the present experiment it was observed that an amount of Rs. 1793.00/ha could be saved due to fertilizer saving in the treatment with site specific drip fertigation and daily drip irrigation, when compared with the treatment recommended dose drip fertigation and daily drip irrigation, though the difference in yield among these two treatments were only Rs.96.00/ha. This is the reason for recording high BCR for the treatment with site specific drip fertigation daily drip irrigation, compared to other treatments in high fertility area.

The results of the present study indicate fertilizer recommendations are to be made based on the existing fertility status of the fields, rather than going for blanket recommendations for all the fields. Site specific drip fertigation with daily drip irrigation is the best treatment for obtaining maximum profit from unit area of land, both in case of low fertility area and high fertility area.

\section{SUMMARY AND CONCLUSION}

The results obtained from the field experiments are summarized below. Fruit length increased with increased rate of fertigation in the low fertility area, whereas no significant increase in fruit length was observed with increased rate of fertilizer application in high fertility area. Highest fruit length of $16.52 \mathrm{~cm}$ was recorded for the treatment site specific drip fertigation and daily drip irrigation in case of low fertility area followed by $15.93 \mathrm{~cm}$ for site specific drip fertigation with alternate day drip irrigation. The lowest fruit length was observed for the treatment with manual fertilizer application and alternate day drip irrigation.

Weight of fruit varied directly with the rate of fertilizer applied in case of low fertility area, whereas there was no significant effect of applied fertilizer on fruit weight in case of high fertility area. The method of fertilizer application had significant effect on fruit weight in high fertility area. The highest number of fruits obtained for low fertility area was (119.33) under site specific drip fertigation providing daily drip irrigation, which was comparable with that for site specific drip fertigation and recommended dose drip fertigation with daily drip irrigation (119.20 and 119.23 respectively) under high fertility area.

The total green fruit yield/ plant recorded with site specific drip fertigation along with daily drip irrigation for low fertility area was $1183.619 \mathrm{~g} /$ plant, which was comparable with that for site specific drip fertigation and recommended dose drip fertigation providing daily drip irrigation for high fertility area (1191.380 and 1191.936 
$\mathrm{g} /$ plant respectively). There was a significant difference in total green fruit yield owing to different moisture regimes by different intervals of drip irrigation in both fertility areas. The highest total green fruit yield (25.493 $\mathrm{t} / \mathrm{ha}$ ) was recorded under the treatment site specific drip fertigation with daily drip irrigation for low fertility area, whereas there was no significant difference between the total yield under the treatments viz. site specific drip fertigation and recommended dose drip fertigation along with daily drip irrigation for high fertility area (25.66 and $25.672 \mathrm{t} / \mathrm{ha}$ respectively).

The Benefit - Cost Ratio (BCR) values worked for various treatments show that in case of low fertility area, highest BCR was recorded with the treatment site specific drip fertigation and daily drip irrigation (2.42) followed by the treatment with site specific drip fertigation and alternate day drip irrigation (2.25). The lowest BCR was recorded under the treatment with manual application of fertilizer and alternate day drip irrigation (1.91). In case of high fertility area, corresponding values of BCR were 2.47. 2.43 and 2. 17 respectively. In low fertility area, though there was an additional cost of Rs.238.00/ha for fertilizer in the treatment with site specific drip fertigation and daily drip irrigation when compared with recommended dose drip fertigation and daily drip irrigation, there was an additional return of Rs. 22800.00 /ha by way of increased yield due to site specific drip fertigation. In high fertility area, the impact of site specific drip fertigation was by way of savings in fertilizer cost. In the present experiment it was observed that an amount of Rs. 1793.00/ha could be saved due to fertilizer saving in the treatment with site specific drip fertigation and daily drip irrigation, when compared with the treatment recommended dose drip fertigation and daily drip irrigation, though the difference in yield among these two treatments were only Rs.96.00/ha.

From the above results it was concluded that fertilizer recommendations are to be made based on the existing fertility status of the fields, rather than going for blanket recommendations for all the fields. Adoption of site specific drip fertigation with daily drip irrigation in hybrid chilli is a viable proposition for the farmers who aim for greater income benefits utilizing optimal inputs. Site specific drip fertigation with daily drip irrigation would be an ideal practice to achieve greater income from unit land area.

\section{REFERENCES}

[1] Hagin, J. and A. Lowengart. 1995. Fertigation for minimizing environmental pollution by fertilizers. Fertilizer Research. Kluwer Academic Publishers 1995/1996. 43(1/3): 127-130.

[2] Magen, H. 1995. Fertigation: An overview of some practical aspects. Fert. News, 40 (12): $97-100$.

[3] Murugappan, V., Bhaskaran, A., Murugesaboopathy, P., Natesan, R., Santhi, R. and Jagadeeswaran, R. 2004. Decision Support System for Integrated Fertilizer Recommendation (DSSIFER) - A management technology released during 2004. Publisher: Directorate of Publications, Tamil Nadu Agricultural University, Coimbatore. No. 20/2004 : 39-40.

[4] Palaniappan. S. P. 1985. Cropping systems in the tropics- Principles and Management. Wiley Eastern Ltd., New Delhi, p. 215.

[5] Panse, V.G. and P.V. Sukhatme. 1978. Statistical method for agricultural workers, II Edn. ICAR, New Delhi, India. Prabhakar, M. and S.S. Hebbar. 1999. Micro irrigation and fertigation in capsicum and tomato. In proc. of National Seminar on Problems and prospects of micro irrigation - A critical appraisal held on Nov. 19-20, 2000 at Bangalore, : 60-68.

[6] Selvaraj, P.K. 1997 Optimization of irrigation scheduling and nitrogen fertigation for maximizing the water use efficiency of turmeric in drip irrigation Ph.D Thesis submitted to Tamil Nadu Agricultural University, Coimbatore.

[7] Shirgure, P.S., Lallan Ram, R.A. Marathe and R.P. Yadhav. 1999. Effect of nitrogen fertigation on vegetative growth and leaf nutrient content of acid lime (Citrus aurantifolia Swingle) in Central India. Indian J. Soil Conservation, 27(1): 45-49.

[8] Sivanappan, R.K. and M.V. Ranghaswami. 2005. Technology to take 100 tons per acre in sugarcane. Kissan world, 32(10): 35-38. 